\title{
PEMBELAJARAN PENDIDIKAN KEWARGANEGARAAN DALAM PENGIMPLEMENTASIAN PENDIDIKAN KARAKTER
}

\author{
Desnita Fitriani \& Dinie Anggraeni Dewi \\ Pendidikan Guru Sekolah Dasar Universitas Pendidikan Indonesia \\ desnita@upi.edu \& anggraenidewidhinie@upi.edu
}

\begin{abstract}
Abstrak
Penelitian ini merupakan analisis kritis terhadap literatur yang relevan untuk membangun peran Pendidikan karakter. Pendidikan karatkter merupakan salah satu pilihan yang tepat untuk membentuk karakter generasi muda. Situasi generasi muda di Indonesia saat ini dalam posisi yang sangat mengganggu. Berbagai kasus yang melibatkan generasi muda semakin meningkat dan menunjukkan bahwa ada kerusakan moral, yang menunjukkan bahwa generasi muda tidak memiliki karakter yang baik lagi, untuk itu diperlukan pendidikan karakter. salah satu sarana untuk mewujudkannya untuk generasi mendatang yaitu dengan dilakukan melalui Pendidikan Kewarganegaraan. Harapan dari pembelajaran Pendidikan Kewarganegaraan dapat meremajakan karakter siswa yang lambat laun merosot agar sejalan dengan nilai Pancasila.
\end{abstract}

Kata Kunci: Pendidikan, karakter, Pendidikan Kewarganegaraan.

\begin{abstract}
This study is a critical analysis of relevant literature to build the role of character education. Character education is one of the right choices to shape the character of the younger generation. The current situation of the younger generation in Indonesia is in a very disturbing position. Various cases involving the younger generation are increasing and show that there is moral damage, which shows that the younger generation does not have a good character anymore, for that character education is needed. One of the means to make it happen for future generations is through Citizenship Education. The hope of learning Citizenship Education can rejuvenate the character of students who gradually decline to be in line with the values of Pancasila.
\end{abstract}

Keywords: Education, character, Citizenship Education.

\section{PENDAHULUAN}

Pendidikan pada dasarnya bertujuan untuk membentuk karakter peserta didik (Rachman et al., 2021). Tujuan yang diharapkan dalam pendidikan tertuang dalam Undang-Undang Nomor 20 Tahun 2003 tentang sistem Pendidikan Nasional dalam pasal 3 yang isinya adalah "Pendidikan nasional berfungsi mengembangkan dan membentuk watak serta peradaban bangsa yang bermartabat dalam rangka mencerdaskan kehidupan bangsa, bertujuan untuk berkembangnya potensi peserta didik agar menjadi manusia yang beriman dan bertakwa kepada Tuhan Yang Maha Esa, berakhlak mulia, sehat, berilmu, cakap, kreatif, mandiri, dan menjadi warga Negara yang demokratis serta bertanggungjawab".
Berdasarkan hal tersebut, jelas bahwa tujuan pendidikan di setiap jenjang sangat diarahkan pada pembentukan karakter bagi peserta didik (Dewantara, Hermawan, et al., 2021).

Pendidikan karakter terdiri dari dua kata, pendidikan dan karakter. Pendidikan adalah berusaha keras untuk meningkatkan karakter dan pemikiran, untuk mempromosikan kehidupan yang harmonis dengan alam dan orangorangnya. Pengetahuan adalah kebutuhan untuk mewujudkan kehidupan masa depan yang gemilang (Dewantara, Nurgiansah, et al., 2021). Usaha tersebut bisa termasuk proses memperoleh pengetahuan, dan kemudian diterapkan dalam kehidupan dan mendapatkan kehidupan yang fungsional. Pengertian karakter yaitu 
bawaan, hati, jiwa, kepribadian, budi pekerti, perilaku, personalitas, sifat, tabiat, tempramen, watak. Karakter merupakan keseluruhan kodrati dan disposisi yang telah dikuasai secara stabil yang mendefinisikan seseorang individu dalam keseluruhan tata perilaku yang menjadikan tipikal dalam cara berfikir dan bertindak. Selain itu menurut Zainal dan Sujak (2011: 2) (Nurgiansah, 2020c) menyatakan karakter mengacu pada serangkaian sikap (attitudes), perilaku (behaviors), motivasi (motivation), dan keterampilan (skills). Karakter berasal dari bahasa Yunani yang berarti "to mark" atau menandai dan memfokuskan bagaimana mengaplikasikan nilai kebaikan dalam bentuk tindakan atau tingkah laku (Nurgiansah, 2021d).

Karakter yang dimiliki seseorang juga akan berdampak besar pada kelompoknya, apakah itu kelompok kecil seperti keluarga, masyarakat, negara, atau bahkan kelompok besar seperti negara. Hal ini sejalan dengan pandangan yang dikemukakan oleh Cicero yang menyatakan bahwa "status warga negara terletak pada kesejahteraan negaranya" (Nurgiansah, 2020b). Hal ini jelas menunjukkan bahwa kumpulan karakter dari seorang individu mempengaruhi kesejahteraan negara. Karakter adalah kekuasaan, dan kekuasaan akan mengontrol kehidupan suatu negara agar tidak terpengaruh. Jika warga suatu negara memiliki karakter yang baik, maka masa depan negara tersebut mungkin juga baik. Kebalikannya juga benar, jika warga suatu negara memiliki kepribadian yang buruk, maka kehidupan di negara itu juga mungkin buruk (Nurgiansah, 2021c).

Kita bisa menghubungkannya dengan situasi di negara saat ini. Masalah karakter terjadi hampir di semua aspek, mulai dari lingkungan keluarga, sekolah, masyarakat biasa, bahkan pejabat yang mewakili pejabat pemerintah (Nurgiansah, 2021a). Masalah karakter yang muncul dari perilaku buruk warga dapat dilihat dalam pemberitaan berbagai media massa, baik itu media cetak maupun media elektronik. Hampir setiap hari, media massa dengan kejam memberitakan kejahatan yang dilakukan oleh warga negara kita, apakah itu kejahatan biasa atau kejahatan luar biasa yang sangat tidak dapat ditoleransi (Nurgiansah, 2020a).

Ironisnya, ketika kita sering mendengar informasi tentang pelanggaran moral siswa di TV, radio dan surat kabar, seperti ngebut di jalan, penggunaan narkoba, dan seks bebas yang berujung pada kehamilan di luar nikah. Tidak hanya itu, setelah menyelesaikan UN, mereka berpencar di jalan raya, berbaris, memanjat tembok, bahkan ada yang terlibat pertempuran. Hal ini menunjukkan bahwa adanya moralitas yang rendah yang disebabkan oleh pendidikan moral di sekolah yang kurang efektif. Penyelengaraan pendidikan karakter menjadi suatu hal yang mutlak dilakukan di jenjang pendidikan manapun karena pendidikan merupakan pondasi utama bagi tumbuh kembang generasi muda (Nurgiansah, 2021f).

Berdasarkan grand design pendidikan karakter tahun 2010, diuraikan bahwa pada lingkungan sekolah terdapat empat pilar yang dapat dijadikan sebagai wadah penanaman nilainilai karakter (Nurgiansah, 2021g). Di antara keempat wadah tersebut yaitu kegiatan belajar mengajar di kelas yang terintegrasi pada setiap mata pelajaran, kegiatan keseharian dalam bentuk budaya satuan pendidikan (school culture), kegiatan ko-kurikuler dan/atau ekstrakurikuler, serta kegiatan keseharian di rumah, dan dalam masyarakat (Nurgiansah, 2021e).

Berdasarkan keempat hal yang dapat dijadikan wadah dalam pelaksanaan pendidikan karakter di sekolah, peneliti menganggap bahwa kegiatan belajar mengajar di kelas merupakan kegiatan inti yang dilaksanakan di sekolah sehingga 
penerapan pendidikan karakter yang terintegrasi pada setiap mata pelajaran merupakan salah satu aspek yang harus mendapat perhatian khusus. Kegiatan belajar mengajar pada setiap mata pelajaran dapat mengintegrasikan nilainilai karakter yang hendak dicapai pada tiap tahap, yaitu perencanaan, pelaksanaan, dan evaluasi, termasuk juga dalam pembelajaran PKn (Nurgiansah, 2021b). Apalagi dalam hal ini, peran mata pelajaran PKn merupakan leading sector dari pendidikan karakter sudah jelas harus mengintegrasikan nilai-nilai karakter dalam kegiatan belajarmengajarnya karena hal tersebut sudah jelas diuraikan dalam tujuan pembelajaran PKn yaitu: Membina moral yang diharapkan dapat diwujudkan dalam kehidupan sehari-hari, yaitu perilaku yang memancarkan iman dan takwa terhadap Tuhan Yang Maha Esa dalam masyarakat yang terdiri dari berbagai golongan agama, perilaku yang bersifat kemanusiaan yang adil dan beradab, perilaku yang mendukung persatuan bangsa dalam masyarakat yang beraneka ragam kepentingan, perilaku yang mendukung kerakyatan yang mengutamakan kepentingan bersama di atas kepentingan perorangan dan golongan sehingga perbedaan pemikiran, pendapatan, ataupun kepentingan di atas melalui musyawarah dan mufakat, serta perilaku yang mendukung upaya untuk mewujudkan keadilan sosial bagi seluruh rakyat Indonesia (Nurgiansah, 2020d).

Berdasarkan tujuan tersebut dapat dipahami bahwa pembelajaran PKn merupakan pembelajaran yang muatannya penuh dengan nilai-nilai karakter. Namun, Permasalahan yang peneliti dapatkan di lapangan adalah praktek pendidikan dalam pembelajaran $\mathrm{PKn}$ yang berlangsung di kelas pada saat ini hanyalah sebatas pendidikan yang berorinetasi pada pencapaian tujuan kognitif atau pengetahuan saja. Sedangkan afektif, hal yang berkaitan dengan proses pembentukan karakter/sikap siswa cenderung diabaikan.

Oleh karena itu, perlunya perbaikan dalam pembelajaran PKn dalam mengembangkan karakter siswa karakter mulai dari perencanaan, pelaksanaan, dan evaluasi (Nurgiansah, Hendri, et al., 2021). Kita harus mampu melakukan perencanaan, pelaksanaan, dan evaluasi yang bisa menginternalisasikan nilainilai karakter yang ada karena penanaman nilainilai karakter tidak cukup hanya sekedar diajarkan tetapi juga harus dikembangkan. Seperti yang dikemukakan oleh Hermann dalam (Budimansyah, 2010: 68) (Nurgiansah, Pratama, et al., 2021)bahwasanya "value is neither cought nor taught, it is learned". Hal tersebut dilakukan agar sebagai seorang pendidik kita mampu meghasilkan anak-anak yang tidak hanya pintar tetapi juga berkarakter (Nurgiansah et al., 2020). Merujuk pada berbagai uraian masalah yang telah saya kemukakan di atas, maka saya termotivasi untuk meneliti tentang "Integrasi Pendidikan Karakter Dalam Pembelajaran Pendidikan Kewarganegaraan Untuk Mengembangkan Karakter Siswa".

\section{METODE PENELITIAN}

Dalam penentuan data ini terdapat 2 (dua) buah data yang terkumpul oleh penulis antara lain: Data Primer, adalah data yang diperoleh secara langsung dari subjek penelitian dengan menggunakan alat pengukuran/alat pengambilan data langsung kepada subjek sebagai sumber informasi yang dicari. Data Sekunder, adalah data yang diperoleh secara tidak langsung dari sumbernya, biasanya diambil melalui dokumen atau melalui orang lain, Data sekunder ini akan diperoleh dari literatur, buku terkait dan jurnal-jurnal yang berkaitan (Nurgiansah \& Al Muchtar, 2018). 
Penelitian ini menggunakan pendekatan kualitatif dengan metode studi kasus untuk mengetahui respon beberapa responden tentang seberapa terpengaruhnya kesehatan mental anak dari tekanan serta pola asuh keluarga. Google form dipilih sebagai lokasi/media penelitian karena tidak bisanya untuk turun kelapangan akibat pandemic Covid-19. Penelitian ini mengambil beberapa mahasiswa sebagai responden dalam proses pengumpulan data. Hasil pengumpulan data yang diperoleh kemudian dianalisis menggunakan model Milles dan Huberman. Teknis analisis tersebut terdiri dari reduksi data, penyajian data, dan verifikasi data (Milles dan Haberman, 2012) (Nurgiansah \& Sukmawati, 2020). Data yang berhasil diperoleh kemudian divalidasi menggunakan teknik pengumpulan data

\section{HASIL PENELITIAN DAN PEMBAHASAN Hasil Penelitian}

Berdasarkan hasil penelitian yang penulis lakukan dari beberapa pertanyaan yang telah penulis ajukan responden menjawab dengan singkat dan sesuai dengan apa yang penulis butuhkan. Dari seluruh responden setuju bahwa Pendidikan karakter sangat dibutuhkan untuk generasi remaja saat ini agar tidak terjadinya penyimpangan moral aataupun kenakalan remaja. Sebagian dari responden pernah melakukan kenakalan remaja atau perilaku penyimpangan moral. Dari seluruh responden tersebut dapat disimpulkan bahwa Pendidikan Kewarganegaraan merupakan wadah bagi para pengajar untuk mengembangkan Pendidikan karakter kepada siswa dikarenakan dalam Pendidikan Kewarganegaraan terdapat materi tentang bela serta cinta negara yang mana jika para remaja melakukan penyimpangan moral maka mereka dapat dikatakan tidak mencintai tanah air atau negara.
Selain

itu

Pendidikan

Kewarganegaraan mencakup nilai-nilai Pancasila yang memiliki nilai karakter dari setiap silanya, yang mana dapa mengembangkan Pendidikan karakter menjadi lebih mudah dan terarah. Semua responden menyetujui bahwasannya Pendidikan karakter sangat mempengaruhi kehidupan remaja di masa depan, dikarenakan karakter yang buruk tidak akan dapat diterima dalam lingkungan masyarakat sekitar maupun nasional, karena karakter yang buruk tidak dapat ditolerir dalam dunia kerja.

Selain itu juga karena Pendidikan karakter sangat diperlukan bagi orang dewasa dikarenakan di zaman sekarangpun para orang tua masih banyak yang masih memiliki karakter yang buruk yang dimana karakter tersebut dapat ditiru oleh para anak dan diterapkan dalam kehidupannya dan mereka anggap benar.

Jadi dapat penulis simpulkan bahwa Pendidikan Karakter merupakan Pendidikan yang memang harus ditanamkan kepada remaja melalui Pendidikan Kewarganegaraan dikarenakan kegiatan anak banyak dihabiskan di dalam sekolah, selain itu juga peran orang tua juga mempengaruhi karakter anak dikarenakan orang tua merupakan cerminan ataupun panutan bagi anak.

\section{Pembahasan \\ Pendidikan Kewarganegaraan}

PKn diambil dari istilah Civic Education, dan oleh sebagian pakar diterjemahkan ke dalam Bahasa Indonesia menjadi Pendidikan Kewargaan dan Pendidikan Kewarganegaraan. Istilah Pendidikan Kewargaan diwakili oleh Azyumardi Azra dan Tim ICCE (Indonesian Center for Civic Education), sedangkan istilah Pendidikan Kewarganegaraan diwakili oleh Zamroni, Muhammad Numan Soemantri, Udin. S. Winataputra, dan Tim 
CICED (Center Indonesian for Civic Education) (Winataputra, 2012).

Soemantri (2001) mengemukakan bahwa mata pelajaran PKn adalah program pendidikan yang berintikan demokrasi politik yang diperluas dengan sumbersumber pengetahuan lainya, pengaruhpengaruh positif dari pendidikan sekolah, masyrakat dan orang tua, yang kesemuanya itu diproses guna melatih para siswa untuk berfikir kritis, analitis, bersikap dan bertindak demokrartis dalam mempersiapkan hidup demokratis yang berdasarkan pancasila dan UUD 1945. Sejalan dengan hal tersebut Azis Wahab, PKn merupakan media pengajaran yang meng-Indonesiakan para siswa secara sadar, cerdas, dan penuh tanggung jawab. Karena itu, program PKn memuat konsepkonsep umum ketatanegaraan, politik dan hukum negara, serta teori umum yang lain yang cocok dengan target tersebut (Cholisin, 2013).

Pada prinsipnya PKn mempersiapkan generasi muda dengan bekal yang cukup mempuni dalam pergaulan kehidupan yang dibutuhkan. Kemampuan berpikir kritis, tanggung jawab, mempunyai sikap dan tindak yang demokratis menjadi media pendukung dalam pembentukan karakter bangsa.

Tujuan PKn adalah partisipasi yang penuh nalar dan tanggung jawab dalam kehidupan politik dari warga negara yang taat kepada nilai-nilai dan prinsip-prinsip dasar demokrasi konstitusional Indonesia (Wahab \& Sapriya, 2011). Partisipasi warga negara yang efektif dan penuh tanggung jawab memerlukan penguasaan seperangkat ilmu pengetahuan dan keterampilan intelektual serta keterampilan untuk berperan serta. Partisipasi yang efektif dan bertanggung jawab itu pun ditingkatkan lebih lanjut melalui pengembangan disposisi atau watak-watak tertentu yang meningkatkan kemampuan individu berperan serta dalam proses politik dan mendukung berfungsinya sistem politik yang sehat serta perbaikan masyarakat.

PKn memberikan harapan yang dapat membawa dan menggiring generasi muda memiliki tingkah laku sesuai dengan tujuan PKn yang akan membawa bangsa pada karakter yang diinginkan melalui proses wahana PKn dengan bekal yang baik dalam komposisi pelajaran yang dipelajari oleh peserta didik, dengan demikian harapan baru harapan national building dapat terwujud. Pada hakikatnya, pengajaran PKn berbeda dengan pengajaran pendidikan lain yang menuntut ketepatan, karena dalam pembelajaran PKn lebih berkaitan dengan masalah-masalah sosial yang sulit untuk mendapatkan ketepatan. Ide pokok pada PKn dapat membentuk warga negara yang ideal sesuai dengan prinsip-prinsip kewarganegaraan, warga negara yang beriman dan bertaqwa kepada Tuhan Yang Maha Esa, memiliki watak pribadi yang baik, berpengetahuan, mempunyai keterampilan dalam menyelesaikan masalah-masalah sosial (social life skill).

\section{Karakter Bangsa}

Karakter adalah watak, tabiat, akhlak, atau kepribadian seseorang yang terbentuk dari hasil internalisasi berbagai kebajikan (virtues) yang diyakini dan digunakan sebagai landasan untuk cara pandang, berpikir, bersikap, dan bertindak. Kebajikan terdiri atas sejumlah nilai, moral, dan norma, seperti jujur, berani bertindak, dapat dipercaya, dan hormat kepada orang lain. Interaksi seseorang dengan orang lain menumbuhkan karakter masyarakat dan karakter bangsa (Rahmatiani).

Relevansi secara umum mengenai karakter dapat dikatakan sebagai pola pikir dan pola perilaku yang menjadi ciri khas tiap individu, dalam pergaulan kehidupan baik lingkup keluarga, masyarakat, bangsa dan negara. Nilai karakter merupakan 
salah satu aspek yang harus menjelma pada setiap insan manusia dan dilakukan dalam setiap aktivitas insan manusia dalam pola kehidupan. Penguatan revolusi karakter bangsa melalui PKn yang menanamkan budi pekerti, mendukung pembangunan karakter generasi muda sebagai bagian dari revolusi mental, yang termasuk sebagai arah orientasi program penguatan pendidikan karakter yang menjadi paradigma pembangunan nasional.

Manusia Indonesia yang berkarakter kuat adalah manusia yang memiliki sifatsifat, sebagai berikut: religius, moderat, cerdas, dan mandiri. Sifat religius, dicirikan oleh sikap hidup dan kepribadian taat beribadah, jujur, terpercaya, dermawan, saling tolong menolong, dan toleran. Sifat moderat, dicirikan oleh sikap hidup yang tidak radikal dan tercermin dalam kepribadian yang tengahan antara individu dan sosial, berorientasi materi dan ruhani, serta mampu hidup dan kerjasama dalam kemajemukan. Sifat cerdas, dicirikan oleh sikap hidup dan kepribadian yang rasional, cinta ilmu, terbuka, dan berpikiran maju. Sikap mandiri, dicirikan oleh sikap hidup dan kepribadian merdeka, disiplin tinggi, hemat, menghargai waktu, ulet, wirausaha, kerja keras, dan memiliki cinta kebangsaan yang tinggi tanpa kehilangan orientasi nilai-nilai kemanusiaan universal dan hubungan antar peradaban bangsabangsa (Juliardi, 2015).

Karakter dimaknai sebagai nilai utama yang melekat pada setiap insan manusia sebagai warga negara yang kemudian diejawantahkan sebagai personalitas diri serta penanda identitas kolektif bangsa. Dalam konteks suatu bangsa, karakter berfungsi sebagai kekuatan identitas dan kekuatan mental bangsa yang mendorong suatu bangsa dalam merealisasikan cita-cita dan tujuan pembangunan bangsa, dengan menampilkan keunggulan-keunggulan yang kompetitif, komparatif dan dinamis di antara bangsa-bangsa lain.

\section{Implementasi Pendidikan Karakter Melalui Pendidikan Kewarganegaraan}

Komitmen nasional tentang perlunya pendidikan karakter tertuang dalam undang-undang No. 20 Tahun 2003 tentang Sistem Pendidikan Nasional, dalam Pasal 3 yang dinyatakan bahwa "Pendidikan nasional berfungsi mengembangkan kemampuan dan membentuk watak serta peradaban bangsa yang bermartabat dalam rangka mencerdaskan kehidupan bangsa, bertujuan untuk berkembangnya potensi peserta didik agar menjadi manusia yang beriman dan bertakwa kepada Tuhan Yang Maha Esa, berakhlak mulia, sehat, berilmu, cakap, kreatif, mandiri, dan menjadi warga Negara yang demokratis serta bertanggung jawab."

Disini dapat diasumsikan bahwa pada umumnya sasaran pendidikan karakter adalah seluruh warga Negara dan secara khusus adalah peserta didik di setiap jenis dan jenjang pendidikan.Berkaitan dengan peserta didik, mereka dikatakan. Sebagai generasi penerus bangsa dan merupakan warganegara hipotetik, yakni warganegara yang "belum jadi",karena masih harus dididik menjadi warganegara dewasa yang sadar akan hak dan kewajibannya.

Di sisi lain, masyarakat sangat mendambakan generasi mudanya dipersiapkan untuk menjadi warganegara yang baik dan dapat berpartisipasi dalam kehidupan masyarakat dan negaranya, bertanggung jawab, memiliki sopan santun, berkeadaban, menghormati orang lain, dan karakter lainnya.Salah satu media yang paling tepat untuk menghidupkan kembali karakter yang dimaksud adalah PKn, dalam artian bahwa nilai-nilai dalam pendidikan karakter diimplementasikan dalam PKn melalui proses integrasi. 
Integrasi nilai pendidikan karakter adalah suatu sistem penanamannilai-nilai karakter kepada warga sekolah yang meliputi komponen pengetahuan, kesadaran atau kemauan, dan tindakan untuk melaksanakan nilai-nilai tersebut, baik terhadap Tuhan Yang Maha Esa (YME), diri sendiri, sesama, lingkungan, maupun kebangsaan sehingga menjadi manusia insan kamil. Sementara itu, beberapa nilai yang perlu dikembangkan di dalam Pendidikan karakter adalah nilai ketaqwaan, nilai keimanan, nilai kejujuran, nilai kepedulian, hingga nilai etika atau sopan santun.

Jika nilai pendidikan karakter diimplementasikan melalui PKn, maka dapat dikatakan bahwa nilai-nilai karakter untuk PKn meliputi nilai karakter pokok dan nilai karakter utama. Nilai karakter pokok PKn yaitu untuk menciptakan peserta didik yang: religius, jujur, cerdas, tangguh, Kedemokratisan, dan peduli.

Sedangkan nilai karakter utama PKn yaitu untuk menciptakan peserta didik yang: nasionalis, patuh pada aturan sosial, menghargai keberagaman, sadarakan hak dan kewajiban diri dan orang lain, bertanggung jawab, berpikir logis, kritis, kreatif, dan inovatif, dan mandiri. Nilainilai karakter utama ini dapat dikembangkan lebih luas, untuk upaya memperkokoh fungsi PKn sebagai pendidikan karakter.

Sampai saat ini Pendidikan Kewarganegaraan sudah menjadi bagian inheren dari instrumentasi serta praksis pendidikan nasional untuk mencerdaskan kehidupan bangsa Indonesia melalui koridor "value-based education". Konfigurasi atau kerangka sistemik Pendidikan Kewarganegaraan dibangun atas dasar paradigma sebagai berikut:

1. Pendidikan kewarganegaraan secara kurikuler dirancang sebagai subjek pembelajaran yang bertujuan untuk mengembangkan potensi individu agar menjadi warga Negara Indonesia yang berakhlak mulia, cerdas, partisipatif, dan bertanggungjawab.

2. Pendidikan kewarganegaraan secara teoretik dirancang sebagai subjek pembelajaran yang memuat dimensidimensi kognitif, afektif, dan psikomotorik yang bersifat konfluen atau saling terintegrasi dalam konteks substansi ide, nilai, konsep, dan moral pancasila, kewarganegaraan yang demokratis, dan bela negara.

3. Pendidikan kewarganegaraan secara programatik dirancang sebagai subjek pembelajaran yang menekankan pada isi yang mengusung nilai-nilai dan pengalaman belajar dalam bentuk berbagai perilaku yang perlu diwujudkan dalam kehidupan seharihari dan merupakan tuntunan hidup bagi warga Negara dalam kehidupan bermasyarakat, berbangsa dan bernegara.

Selanjutnya, jika berbicara mengena implementasi pendidikan karakter melalui PKn di setiap jenis dan jenjang pendidikan dapat dilakukan dengan cara berikut:

1. Pendidikan karakter terintegrasi pada setiap materi $\mathrm{PKn}$, dengan sendirinya setiap materi yang adadi beri bobot pendidikan karakter. Pendidik menyusun rencana pembelajaran dengan menautkan prilaku aspek nilai karakter pada indikator dan tujuan pembelajaran serta bahan belajar PKn.

2. Pelaksanaan pembelajaran PKn dengan bahan belajar tentang nilai karakter diuraikan pada proses belajar mengajar melaui tahapan, yaitu pendahuluan, kegiatan inti, dan penutup. Pada pendahuluan prilaku karakter disajikan melalui apersepsi pada kegiatan seharihari peserta didik atau pengalaman mereka terhadap prilaku serta sikap. Selanjutnya dalam kegiatan inti disajikan melalui contoh atau 
penugasan sehingga secara langsung maupun tidak langsung peserta didik belajar berbagai prilaku tentang nilai karakter bersama peserta didik lainnya. Berikutnya pada kegiatan penutup disimpulkan prilaku apa saja yang harus dikusai peserta didik setelah mempelajari konsep karakter. Jadi, dalam proses pembelajaran PKn, pendidik harus mampu menciptakan watak atau karakter kepada setiap peserta didik.

3. Evaluasi pembelajaran PKn yang menerapkan nilai-nilai karakter dilakukan pada pembentukan karakter. Dengan melihat hasil tugas mingguan yang berupa tugas peningkatan karakter/sikap yang dibuat oleh peserta didik, terlihat perubahan dan peningkatan pada diri mereka secara bertahap setiap minggunya. Berdasarkan hasil observasi kegiatan belajar didapatkan perubahan sikap yang cukup baik. Contoh, untuk membentuk karakter tanggung jawab, peserta didik yang tidak berpartisipasi dalam kerja kelompok diberi hukuman yang disepakati bersama.

\section{Berdasarkan grand design} pendidikan karakter tahun 2010, diuraikan bahwa pada lingkungan sekolah terdapat empat pilar yang dapat dijadikan sebagai wadah penanaman nilainilai karakter. Di antara keempat wadah tersebut salah satunya adalah melalui kegiatan belajarmengajar di kelas yang diintegrasikan pada setiap mata pelajaran termasuk dalam hal ini yaitu mata pelajaran PKn. Setiap mata pelajaran yang diberikan pada siswa di kelas diharapkan dapat memberikan dampak pembentukan karakter kepada siswa. Dalam hal ini ada yang disebut dengan dampak instruksional dan dampak pengiring (nurturant effect).

Mata pelajaran PKn sesungguhnya merupakan salah satu mata pelajaran yang kaya akan nilai-nilai karakter. PKn merupakan salah satu leading sector dari pembelajaran berkarakter. Oleh karena itu tujuan karakter yang ditetapkan dalam pembelajaran PKn sesungguhnya merupakan dampak instruksional yang ingin dicapai bukan hanya sebatas dampak pengiring saja.

Namun, pada kenyataan saat ini PKn seakan menjadi mata pelajaran yang tidak dianggap begitu penting karena pelajaran PKn hanya sebatas pada kegiatan menghapal materi dan kurang mampu menjalankan fungsinya sebagai leading sector dari pendidikan karakter. Pada tahap perencanaan pembelajaran, maka yang harus dilakukan adalah mempersiapkan silabus dan Rencana Pelaksanaan Pembelajaran (RPP). Oleh karena itu, pada penelitian ini saya melakukan analisis terhadap silabus dan RPP yang dipersiapkan oleh guru dalam mendukung pembelajaran PKn berkarakter di kelas. Perencanaan pada pembelajaran yang dituangkan pada RPP memiliki fungsi yang besar dalam menyukseskan pendidikan karakter dalam pembelajaran.

Hal ini didukung oleh pendapat yang dikemukakan oleh Mulyasa (2013: 82) yang menguraikan bahwa sedikitnya terdapat dua fungsi RPP dalam menyukseskan pendidikan karakter di sekolah, yaitu:

1. Fungsi perencanaan. Dalam implementasi pendidikan karakter di sekolah, RPP berfungsi untuk mendorong setiap guru agar lebih siap dalam melakukan kegiatan pembelajaran, membentuk kompetensi, dan karakter peserta didik dengan perencanaan yang matang.

2. Fungsi pelaksanaan. Untuk menyukseskan implementasi pendidikan karakter di sekolah RPP harus disusun secara sistematik dan sistematis, utuh dan menyeluruh, dengan beberapa kemungkinan 
penyesuaian dalam situasi pembelajaran yang aktual. Dalam hal ini, materi standar yang dikembangkan dan dijadikan bahan kajian oleh peserta didik harus disesuaikan dengan kondisi dan kebutuhan lingkungan, sekolah, dan daerah. pendapat tersebut jelas menegaskan bahwa seorang guru yang akan memberikan pembelajaran di kelas harus membuat perencanaan mengenai hal-hal apa saja yang akan dilaksanakan dalam pembelajaran di kelas. Begitu pentingnya perencanaan pembelajaran ini, maka pembuatan rencana tersebut harus dilakukan secara baik dan benar.

Jadi dengan adanya pembelajaran Pendidikan Kewarganegaraan hendaknya dapat mempersiapkan para peserta didik untuk menjadi warga negara yang baik dan cakap karakter, berakhlak mulia, cerdas, partisipatif, dan bertanggung jawab.

\section{KESIMPULAN}

Berdasarkan hasil penelitian dan pembahasan yang penulis lakukan dan telah penulis paparkan, maka di simpulkan bahwa Pendidikan karakter bertujuan untuk kembali menghidupkan karakter warga negara yang sesuai dengan nilainilai Pancasila, antara lain nilai ketaqwaan, nilai keimanan, nilai kejujuran, nilai kepedulian, hingga nilai etika atau sopansantun.PKn merupakan salah satu sarana yang tepat untuk mengimplementasikan nilai-nilai dalam pendidikan karakter kepada peserta didik, karena tujuan PKn pada dasarnya adalah untuk menciptakan peserta didik menjadi warga negara yang demokratis dan berkarakter sesuai dengan nilai-nilai Pancasila. Oleh karena itu, pendidikan karakter tepat diimplementasikan melalui PKn dalam membentuk akhlak generasi muda.

Adapun saran yang dapat penulis berikan diantaranya adalah : Memadukan nilai-nilai pendidikan karakter ke dalam pembelajaran

Pendidikan Kewarganegaraan yaitu dengan memasukkan nilai-nilai karakter ke dalam silabus dan rencana pengajaran.

\section{DAFTAR PUSTAKA}

Akbal, M. (2017, October). Pendidikan Kewarganegaraan dalam pembangunan karakter bangsa. In Prosiding Seminar Nasional Himpunan Sarjana Ilmu-Ilmu Sosial (Vol. 2, pp. 485-493).

Armin, Reza. (2015). Strategi dan Implementasi Pendidikan Karakter di SMPN 9 Yogyakarta. Yogyakarta: Universitas Negeri Yogyakarta.

Dewantara, J. A., Hermawan, Y., Yunus, D., Prasetiyo, W. H., Efriani, Arifiyanti, F., \& Nurgiansah, T. H. (2021). Anti-Corruption Education as an Effort to Form Students With Character Humanist and Law-Compliant. Jurnal Civics: Media Kajian Kewarganegaraan, 18(1), 7081.

Dewantara, J. A., Nurgiansah, T. H., \& Rachman, F. (2021). Mengatasi Pelanggaran Hak Asasi Manusia dengan Model Sekolah Ramah HAM (SR-HAM). Edukatif: Jurnal Ilmu Pendidikan, 3(2), 261-269.

Dianti, P. (2014). Integrasi Pendidikan Karakter dalam pembelajaran Pendidikan Kewarganegaraan untuk mengembangkan karakter siswa. Jurnal Pendidikan Ilmu Sosial, 23(1).

Dwintari, J. W. (2017). Kompetensi Kepribadian Guru dalam Pembelajaran Pendidikan Kewarganegaraan Berbasis Penguatan Pendidikan Karakter. Jurnal Pendidikan Kewarganegaraan, 7(2), 51-57. 
Firmansyah, S. (2013). TantanganPenguatan Komitmen Kebangsaan Untuk Membangun Karakter Warga Negara Pada Masyarakat Perbatasan (Doctoral dissertation, Universitas Pendidikan Indonesia).

Harahap, I. P. S., Angin, A. P., \& Hasanah, N. (2019). HUBUNGAN NILAI-NILAI PANCASILA TERHADAP PEMBENTUKAN KARAKTER SISWA KELAS VIII DI SMP YAYASAN PENDIDIKAN ESA PRAKARSA TAHUN PELAJARAN 2018/2019. Jurnal Serunai Pancasila dan Kewarganegaraan, 8(2), 128-135.

Juliardi, B. (2015). Implementasi Pendidikan Karakter Melalui Pendidikan Kewarganegaraan. Jurnal Bhinneka Tunggal Ika, 2(2), 3.

Kurniawan, M. I. (2013). Integrasi Pendidikan Karakter Ke Dalam Pembelajaran Kewarganegaraan Di Sekolah Dasar. Jurnal Pemikiran dan Pengembangan Sekolah Dasar (JP2SD), 1(1), 37-45.

Nasution, A. R. (2016). Urgensi Pendidikan Kewarganegaraan sebagai Pendidikan Karakter Bangsa Indonesia melalui Demokrasi, HAM dan Masyarakat Madani. Jupiis: Jurnal Pendidikan Ilmu-Ilmu Sosial, 8(2).

Nurgiansah, T. H. (2020a). Build An Attitude of Nationalism Students At SDN 7 Kadipaten With The Method of Discusion In The Subject PPKn. Jurnal Serunai Pendidikan Pancasila Dan Kewarganegaraan STKIP Budi Daya Binjai, 9(1), 1-11.

Nurgiansah, T. H. (2020b). Fenomena Prostitusi Online Di Kota Yogyakarta Dalam Persfektif Nilai Kemanusiaan Yang Adil Dan Beradab. Jurnal Kewarganegaraan, 17(1), 27-34. https://doi.org/10.24114/jk.v17i1.14208

Nurgiansah, T. H. (2020c). Filsafat Pendidikan. In Banyumas: CV Pena Persada.

Nurgiansah, T. H. (2020d). Pelatihan Penulisan Artikel Ilmiah Bagi Mahasiswa PPKn Universitas PGRI Yogyakarta. JNPM: Jurnal Nasional Pengabdian Masyarakat, 1(1), 1623.

Nurgiansah, T. H. (2021a). Partisipasi Politik Masyarakat Sleman di Masa Pandemi Covid-19 dalam Konteks Pendidikan Kewarganegaraan. Jurnal Civic Hukum, 6(1), 1-9.

Nurgiansah, T. H. (2021b). Pelatihan Penelitian Tindakan Kelas Bagi Guru Pendidikan Kewarganegaraan Di Sekolah Menengah Atas Se-Kabupaten Bantul. BERNAS: Jurnal Pengabdian Kepada Masyarakat, 2(1), 28-33. https://doi.org/10.31949/jb.v2i1.566

Nurgiansah, T. H. (2021c). Pemanfaatan E-Learning Dalam Pembelajaran Pendidikan Kewarganegaraan. JINTECH: Journal of Information Technology, 2(2), 138-146.

Nurgiansah, T. H. (2021d). Pendidikan Pancasila. In Solok: CV Mitra Cendekia Media.

Nurgiansah, T. H. (2021e). Pendidikan Pancasila Sebagai Upaya Membentuk Karakter Jujur. Jurnal Pendidikan Kewarganegaraan Undiksha, 9(1), 33-41.

Nurgiansah, T. H. (2021f). Petuah Pendidikan Kewarganegaraan Dalam Kontestasi Politik. AoEJ: Academy of Education Journal, 12(1), 39-47.

Nurgiansah, T. H. (2021g). The Role of Citizenship Education in Building Bantul Community Political Participation in The Pandemic Covid 19. Prosiding Seminar Nasional Pendidikan Dan Kewirausahaan, 4(1), 1-4.

Nurgiansah, T. H., \& Al Muchtar, S. (2018). Development of Student Awareness through Student Learning Model Jurisprudential in Citizenship Education. ATLANTIS PRESS, 251(Acec), 670-674. https://doi.org/10.2991/acec-18.2018.150

Nurgiansah, T. H., Dewantara, J. A., \& Rachman, F. (2020). The Implementation of Character Education in the Civics Education Syllabus at SMA Negeri 1 Sleman. Jurnal Etika Demokrasi, 5(2), 110-121.

Nurgiansah, T. H., Hendri, \& Khoerudin, C. M. (2021). Role Playing Dalam Pembelajaran 
Pendidikan Pancasila dan Kewarganegaraan. Jurnal Kewarganegaraan, 18(1), 56-64. https://doi.org/10.24114/jk.v18i1.22597

Nurgiansah, T. H., Pratama, F. F., \& Iman, A. S. (2021). Penelitian Tindakan Kelas Dalam Pendidikan Kewarganegaraan. Jurnal Pendidikan Pancasila Dan Kewarganegaraan, 2(1), $10-23$.

Nurgiansah, T. H., \& Sukmawati. (2020). Tantangan Guru Pendidikan Kewarganegaraan Di Masa Adaptasi Kebiasaan Baru. Jurpis: Jurnal Pendidikan Ilmu Sosial, 17(2), 139-149.

Nursalam. (2017). Peningkatan Hasil Belajar Pkn Melalui Model Pembelajaran Kooperative Tipe Two Stay Two Stray Pada Murid Kelas V SDN 180 Bentenge Kabupaten Bulukumba. Makassar: Universitas Muhammadiah Makassar

Rachman, F., Nurgiansah, T. H., \& Kabatiah, M. (2021). Profilisasi Pendidikan Kewarganegaraan dalam Kurikulum Pendidikan Indonesia. Edukatif: Jurnal Ilmu Pendidikan, 3(5), 2970-2984.

Rahmatiani, L. (2020, September). Pendidikan kewarganegaraan sebagai pembentuk karakter bangsa. In Seminar Nasional Kewarganegaraan (Vol. 2, pp. 87-94).

Seno, D. (2016). IMPLEMENTASI PENDIDIKAN KARAKTER DALAM PEMBELAJARAN PKn KELAS II SD GUGUS LARASATI KOTA SEMARANG (Doctoral dissertation, Universitas Negeri Semarang).

Suardi, S., Herdiansyah, H., Ramlan, H., \& Mutiara, I. A. (2019). Implementasi Pendidikan Karakter Melalui Mata Pelajaran Pendidikan Kewarganegaraan di SMA Jaya Negara Makassar. JED (Journal of Etika Demokrasi), 4(1).

Suwito, A. (2012). Integrasi Nilai Pendidikan Karakter ke dalam Mata Pelajaran Pendidikan Kewarganegaraan di Sekolah Melalui RPP. CIVIS, 2(2/Juli).

Wadu, L. B. PENDIDIKAN KEWARGANEGARAAN MELALUI GEREJA (Studi Kasus Pada Program Aksi Puasa Pembangunan di Paroki St. Yohanes Pemandi Malang). 